\title{
Genre and Ideology in Woody Allen's Another Woman (1988)
}

\author{
Beatriz Oria \\ University of Zaragoza \\ beaoria@unizar.es
}

\begin{abstract}
This paper analyses Another Woman, one of Allen's serious films of the eighties, in the light of two genres traditionally associated with the expression of female subjectivity: melodrama and the woman's film. Taking into account these genres' conventions, I explore the issues of identity crisis and female repression under patriarchy through an analysis of the film's protagonist. With this purpose in mind, Another Woman is read in connection with contemporary debates about feminism. More specifically, my analysis reveals the film's duplicitous ideology: while apparently endorsing female liberation, the text in fact supports a much more conservative standpoint, directly related to the eighties backlash reaction to the achievements of feminism.
\end{abstract}

Despite Allen's primary dedication to comedy - the genre for which he has been unanimously recognised - he has also expressed his interest in tragedy and melodrama in films such as Interiors (1978), September (1987), Another Woman (1988), Melinda and Melinda (2004) or the recent Match Point (2005). Maybe because of their lack of commercial success and popularity among the critics (at least in the case of the first three features), Allen's "serious" films have not received the same amount of scholarly attention as his comedies. One only needs to read a monograph like The Films of Woody Allen (Girgus, 2002) or Woody Allen: New Yorker (McCann, 1990) to realise how little space is devoted to these films in contrast with his most popular comedies, such as Annie Hall (1977), Manhattan (1979) or Hannah and her Sisters (1986). At their best, Allen's serious films have been considered as sidetracks in his career, mere "deviations" from comedy, the genre which has become synonymous with his persona. At their worst, some critics have 
mercilessly slammed these movies: Bert Cardullo, for instance, regards them as "embarrassing episodes" in Allen's filmography, arguing that they represent a "feeble struggle to escape from his more authentic self" (2006: 141). This view implies that Allen's "real self" is unambiguously comic, thus rejecting the possibility that this director may have something to say in the context of serious drama. During the 2000s, this generalised negative view of Allen's serious works seems to have been significantly altered with the commercial and critical success of Melinda and Melinda and especially of Match Point, but Cardullo's argument is representative of scholarly criticism of Allen in the eighties. What the majority of critics overlooked then is that these films might not be as funny and entertaining as might have been expected, but they provide "an opportunity to examine Allen's ideas laid bare, as it were, and to evaluate more clearly Allen's larger, and very real, achievements as a comic filmmaker" (Green, 1991: 70). Indeed, those critics who regarded these films as "minor" works failed to notice that they represent the other side of the coin of Allen's most famous comedies. Similar thematic aspects are approached in them from a different perspective, and the underlying tensions of his "lighter" films are laid bare and openly (and sometimes painfully) explored. Another Woman, for instance, deals with the topic of self-identity and mid-life crisis, a subject that has been tackled on other occasions by Allen, but usually from the point of view of comedy. In this film this issue is approached from a much more serious perspective, as grave reflection and psychological introspection replace jokes and gags, temporarily laying comedy aside in order to draw on more "serious" genres such as melodrama and the woman's film. This essay attempts to constitute a contribution to the critical unravelling of one of these "serious works": Another Woman, a film which has received comparatively little attention on the part of critics. ${ }^{1}$ With this purpose in mind, I will attempt to analyse the use Allen makes of the conventions of melodrama and the woman's film to depict female repression under patriarchy as the source of the protagonist's crisis of identity. This formal analysis will lead to an ideological interpretation of the film in which I will seek to analyse Allen's deployment of the conventions of these two genres in connection with contemporary debates about gender and feminism, in order to elucidate the film's ideological complexity with respect to patriarchal culture.

Barely eighty-five minutes long, Another Woman tells the story of Marion Post (Gena Rowlands), head of the Philosophy Department of a very prestigious college, and her struggle to overcome the repression which has so far shielded her from her emotions and her true self. She is writing a book, and construction noise in her building forces her to rent an apartment where she can work peacefully. However, this apartment is next to a psychiatrist's surgery and due to an "acoustic oddness" she is able to hear the patients' confessions. One day she overhears the conversation between the psychiatrist and Hope (Mia Farrow), a pregnant patient who cries at the realisation that she is deceiving herself, as she leads a successful but empty life, devoid of true passion. The striking resemblance between both women's lives makes Marion more and more interested in Hope's confessions, which motivate the protagonist's reflections about her own life. In this way, she sets off on a journey of self-discovery which will culminate in her recognition of all the things she had 
repressed till then, mainly how her unemotional attitude and her privileging of reason over passion led her to put her career before her personal life and prevented her from marrying the love of her life and having children, her most hidden wish. The recognition of her unemotional attitude leads Marion to consider how her behaviour has affected her and those around her, finally making possible the attainment of her true identity as an emotional being, thus becoming "another woman".

From a theoretical standpoint, almost no film belongs to a single genre; all films draw on different genres, making it impossible to classify them into closed categories. Keeping this in mind, I intend to analyse the particular use Allen makes of the conventions of melodrama and the woman's film in order to highlight the subject matter of female repression in a male dominated society. For this purpose, I will measure Another Woman against traditional notions of melodrama, even though I am aware that Allen's film by no means can be considered "pure" melodrama. In this respect, it should be pointed out that Another Woman is greatly influenced by European art cinema, and more specifically by the work of Ingmar Bergman, which crucially affects our "experience" of the film as spectators. $^{2}$ Allen's film does not openly activate the mechanisms of identification typical of classical melodrama which are necessary for the powerful engagement of the spectator's subjectivity. Instead, the film prefers to appeal to the viewer's intellect. The melodramatic conventions present in Another Woman are sometimes reflexively deployed as elements less to be emotionally reacted to by an "innocent" spectator than reflected upon by a "melodrama-conscious" audience. In addition to this, the high culture implications of some of Another Woman's elements presuppose an ideal spectator different from the audience traditionally associated to melodrama. Instead, Allen's film addresses a cultivated viewer, able to understand the film's numerous intellectual references. Yet, in spite of the particularity of Another Woman's position within the genre, I consider that it does deploy some of the conventions of classical melodrama in a more direct (and traditional) way, and that is what I will attempt to analyse in the following lines.

One of the most important conventions of melodrama in which Another Woman participates has to do with the film's subject matter. In dealing with the middle-age crisis of a character who struggles to attain her true self in spite of social conditionings, Another Woman tackles the melodramatic topic par excellence: the individual's search for identity within a social system that blocks his/her desire. The importance of this topic in Allen's film is already suggested by the very title: Another Woman not only suggests Ken's (Ian Holm) infidelity but also, and more importantly, Marion's discovery of "another woman" in herself, of her true identity.

In this film, the family constitutes the source of Marion's repression and, therefore, the site in which the protagonist's struggle for self-identity has to be carried out. According to Nowell-Smith's classical formulation, melodrama typically deals with "the child's problems of growing into a sexual identity within the family, under the aegis of a symbolic law which the Father incarnates", and what is at stake is "the survival of the family unit and the possibility for individuals of acquiring an identity which is also a place within the system" (1987: 73). This need of finding one's personal identity while still fitting into the social 
system constitutes a central topic in the film, one that basically concerns the siblings: Marion and Paul (Harris Yulin).

At the beginning, Marion seems to have found a good balance between both positions: she is a successful career woman satisfactorily integrated in a social network of family and friends. However, this seemingly well-adjusted situation is deceptive, as the balance between the public and the personal is not really even. The truth is that she has been pushed into that position by her father, to whose authority she is ultimately submitted. In this case his authority, unlike classical patriarchal rule, has not confined her to the home. Instead, it has forced her into the public sphere, making her leave the world of emotion and feeling usually allotted to women, following in her father's steps. It is clear that this is not the typical patriarchal imposition so common in classical Hollywood melodrama. However, a closer look at Marion's situation reveals that she is ultimately subjugated by patriarchal power. On the other hand, the case of Paul follows more conventional patterns of generational struggle between father and son. The father, who cannot live up to his son's expectations, exercises a castrating authority over his children against which Paul (unlike Marion) tries to rebel by refusing to live his life the way his father would like him to. In this case, the patriarchal order that the father imposes subverts classical organizations in which the woman is deprived of opportunities while the man is encouraged to succeed in the public sphere. Indeed, this is not the traditional order, but it is still an order which oppresses Marion and Paul's individuality and which represents a castration threat, especially for Paul, who must give in to patriarchal power and sacrifice his personal wishes in order to find his place in the family.

This reversal of the traditional situation of classical melodrama may be interpreted as a sign of changing times. As a cultural product, cinema holds a complex relationship with its context: it establishes a dialogue with the culture in which it is inscribed, reflecting and constructing at the same time the social climate of a specific historical moment. For this reason, Another Woman cannot be unproblematically measured against classical notions of melodrama. Rather, it should be understood as a melodrama of the late eighties, a period in which feminism had made important advances in its struggle towards the achievement of female liberation. The film is evidence of how, by 1988, the insights and demands of second-wave feminism born in the late sixties had already spread beyond militant and academic circles. Another Woman suggests that this phenomenon also included men, as Marion's father consciously accepts and even supports a new order in which women can enter public life, occupying a higher status than men if necessary, as is the case of Marion and Paul. In accordance with the times, he seems to have assimilated female liberation, advocating its principles by encouraging his daughter to succeed in the public sphere. However, at an unconscious level, he defends the contrary: he does not realise that instead of "encouraging" his daughter, he has actually "pushed" her towards the public world, not allowing Marion to decide for herself, thus imposing on her a modified but equally patriarchal rule. In this way, Another Woman encapsulates the ambivalence towards feminism that is present in the society of the eighties: on the one hand, the film portrays through the figure of the father society's change of attitude towards the independent, 
working woman. On the other, Marion's unhappiness with her "independent" status suggests that Another Woman is actually supporting an ideology radically opposed to the one it seems to defend at first sight: the protagonist's choice of options traditionally associated to the other sex, such as the privileging of one's career over family life and the rejection of values typically regarded as feminine (like motherhood and affection), are presented as the causes for her crisis. Thus, the film shows how women's stepping out of their traditional gender roles only leads to unhappiness and instability. In this sense, Another Woman is one more of the many films which tried to redirect women towards their traditional positions within the home during the decade of the eighties as part of a wider backlash movement against feminism. I intend to analyse the film's underlying ideology and its relationship with its historical context later on.

Returning to the film's use of the conventions of melodrama, the text suggests that in this context a happy ending for Paul and Marion seems impossible, at least from a psychoanalytic point of view, because in the Oedipal structure of melodrama the resolution of the conflict depends on acceptance of authority. According to Nowell-Smith, "a 'happy end' which takes the form of an acceptance of castration is achieved only at the cost of repression" (1987: 73). Indeed, Marion has had to repress her emotional side in order to succeed in her career and this repression comes to the surface through the deep dissatisfaction she feels in her life. Paul, on the other hand, seems to have settled down: he has abandoned his dreams of travelling the world and now has a dull job in an office. $\mathrm{He}$ finally seems to fit the system, but the price for it has been to abandon the dreams of his youth. His character is only sketched by the film since his appearances are very scarce. One of the scenes which tells us more about him takes place in a flashback sequence: Paul and his father are in a cabin in the woods and the father tells him that he must accept a position at his uncle's paper factory so that Marion can go to college. This is a very brief scene, but it suggests very clearly the dynamics of their relationship: unlike Marion, Paul is a disappointment to his father because he refuses to follow in his footsteps. His outbreak of violence after the father leaves is a clear sign of Paul's frustration at the blockage in the development of his own identity under patriarchal impositions. In this scene the generational gap is clearly foregrounded by the mise-en-scène as the father talks to his son through an actual physical barrier, the cabin's door, and also by Paul's resentful words against his parents: "I hate him. Both of them. They live in their own world", which points not only to the generational barrier between parents and son but also to their intellectual and detached nature, which contrasts with his emotional character. In this way we see how Paul, in his troubled father-son relationship, refuses to grow up only in order to become "his father" and occupy his position in the patriarchal order. Even though he is obliged to finally give in so as to find his place in society, total identification with his father is never achieved, as can be seen from the father's words of contempt towards his son in the scene in which Marion goes to visit him.

Marion's relationship with her parents is very different but equally one of repression, and this constitutes the source of her identity crisis as an adult. Unlike her father, who is a constant presence, not much is said about her mother. In fact, she remains absent throughout 
the film: she is only briefly referred to and the only time she appears on screen she is seen from a distance (which points to her actual "absence" and "distance" from Marion's life as a child). The only link which is left between mother and daughter is the book of Rilke's poetry Marion inherited from her. This small detail can tell us a lot about their relationship because it constitutes the clearest sign of identification between the two: the mother was the one who introduced her to German poetry, and like Marion, she also seemed to undergo an identity crisis at middle age, as the tear marks in the book suggest. The film seems to imply that Marion's detached character was inherited from her mother: she remembers that "she loved all beautiful things: nature, music, poetry... That was her whole existence." It is significant that her children are not mentioned among the things that she loved. Everything points to the unemotional character of the mother, who was apparently more concerned with intellectual pursuits than with family life. In this respect, the presence of Clara, the family's servant, is very meaningful: unlike the mother (who does not even have a name) she appears in the film (both young and old) acting as a kind of surrogate mother, as she used to cook for the children and look after them. Marion's most loving words are in fact dedicated to her, not to her mother. In this way, it may be concluded that Marion's subjugation to the father's rule, together with the mother's cold attitude lie at the roots of her repression, which eventually leads to the mid-life crisis depicted by the film.

This repression, however, is rarely openly expressed by the melodramatic text, which tends to channel it through different means. Moreover, the genre's need to bring to the surface hidden material is one of its main characteristics and can be traced back to its origins in nineteenth-century theatre. According to Peter Brooks, melodrama's way of defeating repression is to break through "everything that constitutes the reality principle" and to partake of the "dream world ... saying what is in 'real life' unsayable" (1984: 41). Of course, modern melodrama no longer features characters openly crying out their guilt, their innocence, their love or, in truly melodramatic fashion, their true identity. Nevertheless, although this convention is obviously outdated, the liberating function it entails still constitutes one of the basic elements of the genre, which has to find new ways of voicing the unutterable: in this way, Another Woman replaces straightforward confession from Marion's lips about her repression with more oblique strategies of expression: on the one hand, at the narrative level it is her unconscious that puts into words the unspeakable through Mia Farrow's character and through dreams. On the other, what lies beneath the surface is also conveyed by the mise-en-scène.

The use of mise-en-scène for the outlet of repressed feelings is a mechanism of displacement typical of melodrama which Geoffrey Nowell-Smith describes as "strikingly similar to that of the psychopathology of hysteria." In hysteria what has been repressed returns converted into a bodily symptom. In the same way, repressed material in melodrama is displaced onto the body of the text (1987: 73). In Another Woman, Marion's emotional repression is translated into the mise-en-scène by means of her restrained appearance. The sobriety of her hair and dress, together with her uptight attitude, denote coldness and containment. The same meaning is expressed by the physical spaces in which she moves: her house and the rented flat are spacious and beautifully decorated, but they are not a warm 
environment. Cold colours such as green, grey or yellow predominate in Marion's clothes, as well as in the places she frequents, such as theatres, restaurants, social meetings and private parties which fill her time and are meant to replace passion with socially accepted activities proper of the urban upper-class way of life, trapping Marion in a social network that determines her emotional immobility. In such a network, in which social and sexual roles are well defined, there is no room for illicit passion and her affair with Larry (Gene Hackman) must be put aside for the sake of rationality. Marion's isolation (which is not openly stated by the text, as she appears frequently surrounded by family and friends) is expressed through the mise-en-scène by means of an extreme compartmentalisation of the frame, in which the décor of the home is used to isolate her and highlight her lack of human contact. $^{3}$

In this context, it is worth mentioning the way in which the mise-en-scène comments on the relationships between characters. When Marion and Ken appear together in a scene the mise-en-scène emphasises their detachment and their lack of connection: they are not frequently presented in the same shot, and when they are, direct eye contact between them is scarce and they are usually separated by some element of the décor which delineates a barrier between them. ${ }^{4}$ Sometimes they are not even together in the same room while they talk. A deep feeling of estrangement is produced, for instance, in the scene in which they talk about their anniversary: they keep coming in and out of the room, talking to each other across actual physical barriers, avoiding direct contact. This sense of isolation that surrounds Marion is reversed at the end of the film. When she decides to change, the miseen-scène and camera work reflect her effort to get closer to Paul and Laura (Martha Plimpton), her step-daughter, by showing greater intimacy between them. At the beginning of the film Marion appears to be alienated from the other characters, usually separated by some element of the décor. However, her change of attitude is stylistically enhanced by the breakdown of the "barriers" created by mise-en-scène: by the end of the film she is frequently shot in the same frame as these characters and physical contact is established between them.

The mechanisms of displacement used by the text in order to convey feelings which cannot be openly expressed are not limited to realist representation. Another Woman includes scenes which are not realistically motivated or which break the rules of verisimilitude. To return to the association between melodrama and hysteria, these scenes seem to echo Nowell-Smith's notion of the "hysterical moment." According to him, "the 'hysterical' moment of the text can be identified as the point in which the realist representative convention breaks down" (1987: 74). Another Woman shows such moments in flashbacks, when characters belonging to the past interact with a middle-aged Marion, and also in the dream sequences, when what is repressed comes to the surface. The "hysterical" moment is also suggested in the short scene in which Marion witnesses Laura's conversation with her boyfriend. There is no way Marion can have access to that conversation, so we must conclude that it is a product of her imagination. In her fantasy, Laura puts into words something Marion does not dare recognise yet, that she is "judgmental" and that she "stands above people and evaluates them." Another short but 
relevant "hysterical" moment comes just before the reverie about Laura, when images of a caged panther, a mask and a picture of a pregnant woman suddenly flash out of nowhere, breaking all the conventions of realist representation. These "hysterical" images are symbols that bring to the surface what Marion has repressed: the picture of the woman is a 1903 painting by Gustav Klimt. The eroticism which characterises this artist's oeuvre points to Marion's sexual repression, and the woman's pregnancy symbolises her repressed maternal feelings (the woman in the picture, incidentally, looks very much like Mia Farrow's character, and the fact that both - character and picture - are called Hope reinforces their identification). The mask lying on the floor functions as a symbol for the public persona (in a Jungian sense) that Marion has built to hide her true self. To emphasise this, one of the flashbacks shows a young-looking Marion literally putting on the mask and kissing her first husband through it, as a barrier that protects her from true emotion and filters her passion. Lastly, the caged panther is a reference to Rilke's poem "The Panther." According to Marion's own words in the film, this is a symbol of death, a death that Marion approaches inexorably as she wastes her life in sterile occupations. Marion's need to find her own identity is highlighted through the use of Rilke's poetry, which often deals with the existential quest for a spiritual identity. In this sense, the other poem by Rilke cited in the film, "Archaic Torso of Apollo", plays an important part in the awakening of Marion's repressed self as she reads its last line in an edition streaked by her mother's tears: "For there is no place that does not see you. You must change your life."

Feminist critic Tania Modleski finds in Nowell-Smith's association between melodrama and hysteria a clue to the traditional identification of this genre with the woman's film. Drawing on the fact that medical science and psychoanalysis have traditionally labelled women hysterics, Modleski argues that this is so because in patriarchal culture "their voice has been silenced or repressed, and if melodrama deals with the return of the repressed through a kind of conversion hysteria, perhaps women have been attached to the genre because it provides an outlet for the repressed feminine voice" (1987: 328). Indeed, the woman's film is the best cinematic site for the expression of a particular (and frequently repressed) feminine sensibility. Addressed to a female audience, it usually tackles women's problems and features a female protagonist who is allowed "a significant access to point of view structures and the enunciative level of the filmic discourse" (Doane, 1987: 3). Bearing in mind the difficulty of ascribing films to specific genres, I intend now to analyse Allen's film in connection with the woman's film, a genre which it often approaches.

Despite critical disagreement about the woman's film as a genre, it seems that the common feature of all the films which participate in one way or another in this genre is their address to a female spectator. Female subjectivity is engaged in these films mainly through the deployment of a female point of view. In Another Woman Marion's story-telling agency is the main device used for this purpose. Female identification is also achieved by the film through other devices such as voice-over, Marion's dreams and flashbacks, or the use of images reflecting her unconscious. Another device for the expression of a female point of view is the construction of scenarios of female subjectivity. Laura Mulvey has formerly argued that psychic processes are organised in cinema through Freudian scenarios like 
fetishism and voyeurism. These scenarios are typically masculine, which obliges the female spectator to resort to a "transvestite" option of identification, thus preventing the full engagement of her subjectivity (Mulvey, 1981). According to Mary Ann Doane, the solution provided by the woman's film is to make use of other scenarios which are more appropriate for the portrayal of female subjectivity and which are not so central in the cinematic apparatus. These scenarios include paranoia, hysteria and masochism. The latter seems to be particularly suitable for the woman's film because "in films addressed to women, spectatorial pleasure is often indissociable from pain" (1987: 16). For this author, female identification is very different from male: the latter involves a position of mastery, while the former invariably implies submission: "identification on the part of the female reader or spectator cannot be, as it is for the male, a mechanism by means of which mastery is assured. On the contrary, if identification is even 'provisionally' linked with the woman, ... it can only be seen as reinforcing her submission" (1987: 16). This masochistic position on the part of the woman leads her to the conclusion that the woman's film proposes a "Masochistic fantasy instead of sexuality" (1987: 19).

Another Woman seems to prove Doane right to a point, since the film does display a masochistic fantasy, but the assertion that in the woman's film this fantasy replaces female sexuality is questionable. It is true that in Allen's film, spectatorial pleasure stems mainly from identification with Marion's suffering, assuming therefore a feminine (that is, submissive, masochistic) position. Besides, classical scenarios of voyeurism and fetishism are clearly avoided: Gena Rowlands's image is consistently de-glamorised in this film through very formal, sober clothes and hairstyle, which, far from presenting her as erotic spectacle, desexualise her image and point to her internal restraint. However, this deeroticisation of the male look does not necessarily imply the de-eroticisation of Marion's gaze. Throughout the film, she is clearly presented as a "desiring" subject: her longing for self-identity is closely related to the topic of her sexual identity as a "desiring" woman. Her search for her true self is not resolved until she finally accepts her sexual desire, her passion for Larry. This is clearly seen in the scenes they share: when they are together, his look does involve desire, but she is by no means objectified and turned into the passive object of his gaze: she always returns the look, thus connoting a passion she is afraid to put into words. ${ }^{5}$ It is worth mentioning that, in Allen's film, the female protagonist is the active bearer of the look but, unlike in the classical woman's film, she is not punished by it. ${ }^{6}$ This can be explained as a consequence of feminist advance: in the eighties, denying female desire was no longer acceptable. Rather, Marion is punished for not pursuing that desire, which seems more in accordance with the times. Paradoxically, this reveals a highly traditional ideological standpoint on the part of the film which will be later discussed, since Marion is punished for not pursuing what the film assumes to be the "true" female nature, that is, feeling and emotion.

Apart from the usage of specific Freudian scenarios, another issue worth commenting in relationship with the woman's film genre is Another Woman's formal structure. Critics like Linda Williams have pointed out the difference between "male narratives" which follow a linear progression and encourage identification with male characters who are capable of 
mastering the environment, and female forms in which the spectator tends to identify with much more passive and suffering heroines while the narrative unfolds in a less linear fashion (1987: 301). According to feminist critic Tania Modleski, this lack of linearity in the woman's film can be related to a typically feminine experience of time and place. Unlike the classical Hollywood text, which tends to progress towards an end, melodrama and especially the woman's film "gives the impression of a ceaseless returning to a prior state ... the important moments of the narrative are often felt as eruptions of involuntary memory" (1987: 330). In the case of Another Woman, it is clear how this "typically feminine" experience of time impregnates its narrative, affecting its structure: rather than a straightforward plot in which events succeed one another until a climatic ending is reached, as is the case in most films, Another Woman features quite a muddled plot, full of flashbacks and dream sequences. This is taken to a point in which past or imaginary events become almost more important than real actions taking place in the film's fictional present. Key moments in the narrative such as the protagonist's discovery of Ken's infidelity, her abortion, the reasons for Paul's hate or the affair with Larry are all constructed as flashbacks. Other relevant issues for the understanding of Marion's character and the film's resolution are introduced as - usually involuntary - reveries, as is the case of the long dream sequence in which the protagonist is faced with a series of uncomfortable truths about her present and past - such as her first husband's suicide - or the scene in which she witnesses a conversation in which Laura and her boyfriend talk about her. This kind of scenes abound in the text, interrupting the natural flow of the action and distinguishing Another Woman from other films with more traditional story-telling mechanisms. This is not coincidental, since the director could have chosen a much simpler way of narrating the same story. Another Woman's structure, however, endows the film with a sensibility which relates it directly to the woman's film genre. Julia Kristeva, for instance, establishes a link between the kind of non-linear experience of time featured in Allen's film and female subjectivity. It implies a cyclical idea of time (what she calls the "time of repetition") totally opposed to the "time of history", that is, the linear teleological time typical of the masculine sensibility which dominates most forms of representation (1995: 205-6).

As I have mentioned before, there is a fair amount of confusion concerning the demarcation of the woman's film as a genre. For instance, some critics, such as Doane, do not consider it as a separate genre. Others, like Gledhill, tend to regard it as a sub-set of melodrama. ${ }^{7}$ In addition, feminists like Laura Mulvey make a distinction between those melodramas in which a female point of view acts as a source of identification (the woman's film) and those which deal with male oedipal problems by depicting family tensions (male family melodrama) (1987: 76). In contrast with the latter, which serves patriarchal ends by bringing about a narrative resolution for "irreconcilable social and sexual dilemmas", the woman's film produces narrative problems impossible to tie up (1987: 79). Taking Mulvey's distinction as a cue, my intention now is to explore the ideological contradictions which lie beneath Another Woman, a text which apparently seems to endorse a feminist position, while concealing an underlying anti-feminist discourse.

In his study of film melodrama through the works of D. W. Griffith, King Vidor and 
Vicente Minnelli, Robert Lang sees a clear historical evolution in the basic conflict which lies at the heart of the genre: first the individual had to fight against fate and social injustice, then against social conditions, which led to a struggle for the attainment of an individual identity. It was not until later that it became clear that the real fight was against patriarchy (1989: 3). Ultimately, melodrama's unbalanced representation of the sexes stems from a social construct: the split between the productive and reproductive spheres. Under capitalism, patriarchy has relegated women to the less important (unproductive) sphere. Subordinated to men and reduced to the status of commodities, women are "expected to make the home a haven from the workplace" and to absorb the contradictions caused by the separation of spheres (1989: 9). In this context, the only way for a woman to enter the public sphere is to adopt masculine priorities. As Kristeva puts it, women "cannot gain access to the temporal scene, that is, to the political and historical affairs of our society except by identifying with the values considered to be masculine" (1986: 155). According to her, Western women must choose between identifying themselves with the mother, thus ensuring their marginality within patriarchy, or identifying with the father, which permits access to the symbolic order but reinforces the same patriarchal system which excludes them (1986: 154). Marion chooses the latter option: her deep identification with her father is emphasised in the dream sequence, during which he offers a displaced voicing of his daughter's deepest regrets: not having married the love of her life, her lack of her brother's love and her privileging of a successful professional career over personal life.

Now that my life is drawing to a close I have only regrets. Regrets that the woman I shared my
life with is not the one I loved the most deeply. Regrets that there is no love between my son and
myself. That is my fault. Regrets that perhaps I've been too severe with my daughter, too
demanding, that I haven't given her enough feeling. But I was so unhappy about myself, so
caught up in those stupid studies of historical figures. Even though I have achieved some
eminence in my field, I asked too little of myself.

Through this identification with masculine priorities, Marion has rebelled against the place allotted to her by patriarchy as wife and mother. However, this challenging of the status quo has turned against her, since in order to achieve a relevant social position she has had to neglect the personal sphere and repress her identity as an emotional woman. In this way she is equally trapped by patriarchy because, there is no way she can develop a balanced, adjusted identity capable of satisfying the demands of both family and work outside the home. In this respect, Deborah Thomas's argument that “even so-called female-centred melodramas are much more determined by male fantasies and anxieties than has generally been acknowledged", (2000: 29) would be suitable in this case. Although Another Woman is a woman's film, it is ultimately determined by male anxieties about female liberation because the independent woman is punished with unhappiness by patriarchy and the ending points to her re-direction towards her "proper" position within the realm of the family (and more specifically, her relocation as a mother, a crucial figure for the perpetuation of capitalist social relations and patriarchal dominance) ${ }^{8}$ In this way, Another Woman may be understood to be a sign of the contradictions in the life of a contemporary woman who, 
unlike her predecessors, must satisfy both public and private needs: not only must she have a successful career, but also fulfil her role as mother and wife. The film seems to argue in favour of the latter, as leading an emotionally fulfilling life is eventually regarded as the indispensable condition for the achievement of happiness. Such favouring of the private sphere over the public in relation to the female protagonist may point to a "nostalgia" for the old values which conceals a strong patriarchal standpoint on the film's part.

According to Stephen Neale, melodrama focuses on personal conflicts which take place inside an already established social order, "suggesting not a crisis of that order, but a crisis within it" (1980: 22). If characters in classical melodrama were constrained by a rigid patriarchal order, Another Woman shows an apparent replacement of that order with a new one in which women can step out of the private sphere and have a career. However, this apparent greater freedom is only an illusion, firstly because Marion is still trapped under the rule of patriarchy, and secondly because by presenting a female crisis within this new social order the film is pointing to its inadequacy, arguing in favour of Marion's return to a more traditional female position within the family. The film's ideological statement can thus be read in the light of its historical and social context: according to Susan Faludi, the decade of the eighties saw the emergence of a strong backlash movement against feminism. Born within the ranks of the New Right, it was later popularised by the media, spreading the idea that the reason for women's generalised feeling of dissatisfaction was not inequality, but feminism itself. For Faludi, the media include television (both "serious" journalism and fictional TV series), popular novels, the written press, popular psychology manuals and, of course, cinema. While Hollywood seemed to support the feminist cause in its positive portrayal of women during the seventies with films such as Diary of a Mad Housewife (1970), Up the Sandbox (1972), A Woman under the Influence (1974), Alice Doesn't Live Here Anymore (1974), The Turning Point (1977), Julia (1977), An Unmarried Woman (1978), My Brilliant Career (1979), The China Syndrome (1979), Norma Rae (1979), Private Benjamin (1980) or 9 to 5 (1980), the eighties tended to replace independent heroines with passive female characters and to foreground the incompatibility of career and personal realisation in women's lives (1992: 152-70). By depicting unhappy working women,

women's anger at their social circumstances was depoliticised and displayed as personal depression instead; and women's lives were framed as morality tales in which the 'good mother' wins and the independent woman gets punished. And Hollywood restated and reinforced the backlash thesis: women were unhappy because they were too free; their liberation had denied them marriage and motherhood (1992: 141).

The topic of motherhood is specially salient, since these films tried to promote women's return to the home and to their traditional roles within the family by making motherhood as alluring as possible. This is the case of Baby Boom (1987), Parenthood (1989), Overboard (1987), Immediate Family (1989), or Three Men and a Baby (1987), for instance. Apart from emphasising all the advantages of maternity and none of its drawbacks, backlash movies classified women into two kinds: "the humble women who procreate, and their 
monied or careerist sisters who don't" (1992: 163). In this context, abortion was seen as a kind of moral test to separate the good women from the bad.

Other critics are not so certain in their views of the backlash. For Susan Douglas, for instance, the backlash movement against feminism was already present in the decade of the seventies, and rather than a "simplistic war against women", she sees it as "a complex struggle between feminism and antifeminism that has reflected, reinforced, and exaggerated our culture's ambivalence about women's roles for over thirty-five years" (1994: 12-13). While Faludi's arguments are often very convincing indeed, Douglas's view of the ambivalent role of the media in the representation of women is probably more accurate as a whole. ${ }^{9}$ From my point of view, the tension between feminism and antifeminism proposed by Douglas is also present in Another Woman, even though it may be finally resolved in favour of the latter. The film presents us with a successful, self-assured woman who could be initially regarded as a feminist model of independence. Just as the dominant social order seemed to advocate female liberation until the late seventies, the film also appears to endorse a feminist ideology, which is basically conveyed by its "formal" structure: the deployment of two genres - melodrama and the woman's film - especially suitable for the expression of female subjectivity. However, as the plot advances, it becomes clear that Another Woman's apparent defence of female liberation actually hides a critique of feminism very much in sync with the conservative spirit of the time. Marion's choice of career over family is implicitly condemned by the film's plot by showing her deep dissatisfaction. In this sense, she seems to be very similar to the embittered female protagonists of other eighties films, such as Suspect (1987), Surrender (1987), Broadcast News (1987) and Crossing Delancey (1988) (Faludi, 1992: 156-58). As in the case of these women, a barren emotional life is the price to pay for professional success. Another Woman openly criticises an ideology which may have opened new paths for women but which, according to the film, has only brought them lack of fulfilment, unhappiness and alienation from their "true nature" as women. The film's disapproval of feminist postulates is even more explicit in the "abortion" episode. In line with Faludi's discussion of backlash attitudes, abortion is openly demonised by Allen's film and is used to highlight feminism's shortcomings. In the scene in which Marion and Sam (Philip Bosco), her first husband, argue about her abortion, an explicitly feminist discourse is deployed by Marion in order to defend her position:

I didn't want to have a baby ... it's my life that gets derailed, you go on doing all the things that you want and I have to stop and take care of it and bring it up ... I told you it was not part of my plan ... Consulting you? It's my baby! Do I have to consult you for every move I make?

This is a position which is openly criticised both by Sam, who accuses her of lack of feeling and of privileging the life of the mind, and by the filmic text, which strives to show how wrong Marion's position is.

It can then be concluded that the film is implicitly working against the very point it seems to support at first. By using the conventions of a genre traditionally associated with the expression of female subjectivity, it gives the impression of arguing for an improvement 
of women's position within the status quo. By showing the negative effects that a repressive environment may have in the life of a woman, it seems to be endorsing feminist discourses which demand greater freedom for women. However, the analysis of the film has shown that Another Woman is actually arguing for the contrary. It follows the conventions of melodrama in its story of liberation from repression in order to find one's true identity. However, the resolution to the protagonist's dilemma entails the adoption of an identity clearly connected with traditional discourses of femininity, rather than with the more "progressive" positions the film seemed to advocate at first, This eventually reflects contemporary debates about feminism which seek to reinforce patriarchy in the face of feminist advances. ${ }^{10}$

\section{Notes}

1. However, detailed analyses on Another Woman can be found in Bailey (2001: 255-64), Lee (2002: 118-32), Wernblad (1992: 126-32), Yacowar (1991: 265-73), Nichols (1998: 131-47), Gordon (2004: 218-42) and Asensio (2006: 256-67).

2. Bergman's influence permeates Allen's serious works both in visual and thematic terms. Another Woman in particular is clearly indebted to Wild Strawberries (1957), since both films share similar narrative devices, such as flashbacks and dream sequences, and more obviously, parallel plots.

3. The use of expressive framings and mise-en-scéne has been a recurrent device in Allen's filmography, which has been seen by many critics as another consequence of Ingmar Bergman's influence.

4. This device is also used in order to express Marion's detachment from her brother.

5. It is interesting to compare these scenes with those in which Marion appears with her husband: when she is with Larry they always share deep, intimate looks. However, Marion and Ken rarely look into each other's eyes. The very scarce eye contact which is established between them points to the lack of desire in the couple.

6. According to Mary Ann Doane, female desire has traditionally been represented in the classical woman's film as a dangerous driving force which must be contained. For this reason, desiring female protagonists were usually punished with death by the end of the film (1987: 118-122, 1789).

7. Christine Gledhill, for instance, sees no absolute line of demarcation between the two, as both deal with the "construction and meaning of the domestic, of personal life, and the place of men and women in this" (1987: 36).

8. Another Woman does not do this explicitly because Marion is not a mother, but her very wish to become one and her intentions to tighten her bond with Laura point to her relocation in the domestic sphere, a position which helps the perpetuation of the status quo.

9. Unlike Faludi, Douglas does not regard the media as entirely negative agents in the portrayal of women. Rather, this author concludes that the media "are still our worst enemy and our best ally in our ongoing struggle for equality, respect, power, and love" (1994: 294).

10. Research towards this essay was funded by the Spanish Ministry of Education, project no. BFF2001-2564 and by the DGA (Ref. H12). I would also like to thank Celestino Deleyto for his help in earlier versions of the essay. 


\section{References}

Asensio, María del Mar (2006): "Hlenka Regained: Irony and Ambiguity in the Narrator of Woody Allen's Another Woman". In Charles L. P. Silet, ed., The Films of Woody Allen: Critical Essays. Lanham: Scarecrow, 256-267.

Bailey, Peter J. (2001): The Reluctant Film Art of Woody Allen. Lexington, Kentucky: The University Press of Kentucky.

Brooks, Peter (1984): The Melodramatic Imagination. New York: Columbia UP.

Cardullo, Bert (2006): “Autumn Interiors, or the Ladies Eve: Woody Allen's Bergman Complex". In Charles L. P. Silet, ed., The Films of Woody Allen: Critical Essays. Lanham: Scarecrow, 133-144.

Doane, Mary Ann (1987): The Desire to Desire: the Woman's Film of the 1940s. Bloomington: Indiana UP.

Douglas, Susan J. (1994): Where the Girls Are: Growing Up Female with the Mass Media. New York: Three Rivers.

Faludi, Susan (1992): Backlash: the Undeclared War against Women. London: Vintage.

Girgus, Sam B. (2002): The Films of Woody Allen. Cambridge: Cambridge UP.

Gledhill, Christine (1987): "The Melodramatic Field: an Investigation”. In Christine Gledhill, ed., Home Is Where the Heart Is: Studies in Melodrama and the Woman's Film. London: British Film Institute, 5-39.

Gordon, Jill (2004): "Self-Knowledge in Another Woman". Woody Allen and Philosophy: You Mean my Whole Fallacy Is Wrong? Eds. Mark T. Conrad and Aeon J. Skoble. Chicago; La Salle, IL: Open Court. 218-42.

Green, Daniel (1991): “The Comedian's Dilemma: Woody Allen's 'Serious' Comedy". Literature/Film Quarterly. 19 (2): 70-76.

Kristeva, Julia (1986): “About Chinese Women”. In Toril Moi, ed., The Kristeva Reader. Oxford: Basil Blackwell, 138-59. . (1995): New Maladies of the Soul. New York: Columbia University Press.

Lang, Robert (1989): American Film Melodrama: Griffith, Vidor, Melodrama. Princeton; Guildford: Princeton UP.

Lee, Sander H. (2002): Eighteen Woody Allen Films Analyzed: Anguish, God and Exitentialism. Jefferson, NC; London: McFarland.

McCann, Graham (1990): Woody Allen: New Yorker. Cambridge : Polity Press.

Modleski, Tania (1987): “Time and Desire in the Woman's Film”. In Christine Gledhill, ed., Home Is Where the Heart Is: Studies in Melodrama and the Woman's Film. London: British Film Institute, 326-38.

Mulvey, Laura (1987): “Notes on Sirk and Melodrama”. In Christine Gledhill, ed., Home Is Where the Heart Is: Studies in Melodrama and the Woman's Film. London: British Film Institute, 7579.

. (1981): “Afterthoughts on 'Visual Pleasure and Narrative Cinema' Inspired by King Vidor's Duel in the Sun". Framework 15/16/17: 12-15.

Neale, Stephen (1980): Genre. London: BFI.

Nichols, Mary P. (1998): Reconstructing Woody: Art, Love and Life in the films of Woody Allen. MD: Rowman and Littlefield.

Nowell-Smith, Geoffrey (1987): “Minnelli and Melodrama”. In Christine Gledhill, ed., Home Is 
Where the Heart Is: Studies in Melodrama and the Woman's Film. London: British Film Institute, $70-74$.

Thomas, Deborah (2000): Beyond Genre: Melodrama, Comedy and Romance in Hollywood Films. Dumfrieshire: Cameron and Hollis.

Wernblad, Annette (1992): Brooklyn Is Not Expanding: Woody Allen's Comic Universe. London \& Toronto: Associated University Press.

Williams, Linda (1987): "Something Else Besides a Mother. Stella Dallas and the Maternal Melodrama”. In Christine Gledhill, ed., Home Is Where the Heart Is: Studies in Melodrama and the Woman's Film. London: British Film Institute, 299-325.

Yacowar, Maurice (1991): Loser take all: The Comic Art of Woody Allen. NY: Continuum.

\section{Films Cited}

Letter from an Unknown Woman. Dir. Max Ophüls, 1948.

All that Heaven Allows. Dir. Douglas Sirk, 1955.

The Cobweb. Dir. Vicente Minnelli, 1955.

Written on the Wind. Dir. Douglas Sirk, 1956.

Tea and Sympathy. Dir. Vicente Minnelli, 1956.

Wild Strawberries. Dir. Ingmar Bergman, 1957.

Home from the Hill. Dir. Vicente Minnelli, 1960.

Diary of a Mad Housewife. Dir. Frank Perry, 1970.

Up the Sandbox. Dir. Irvin Kershner, 1972.

Alice Doesn't Live Here Anymore. Dir. Martin Scorsese, 1974.

A Woman under the Influence. Dir. John Cassavetes, 1974.

Annie Hall. Dir. Woody Allen, 1977.

Julia. Dir. Fred Zinnemann, 1977.

The Turning Point. Dir. Herbert Ross, 1977.

An Unmarried Woman. Dir. Paul Mazursky, 1978.

Interiors Dir. Woody Allen, 1978.

Manhattan. Dir. Woody Allen, 1979.

My Brilliant Career. Dir. Gillian Armstrong, 1979.

Norma Rae. Dir. Martin Ritt, 1979.

The China Syndrome. Dir. James Bridges, 1979.

9 to 5. Dir. Colin Higgins, 1980.

Private Benjamin. Dir. Howard Zieff, 1980.

Hannah and her Sisters. Dir. Woody Allen, 1986.

Baby Boom. Dir. Charles Shyer, 1987.

Broadcast News. Dir. James L. Brooks, 1987.

Overboard. Dir. Garry Marshall, 1987.

September Dir. Woody Allen, 1987.

Surrender. Dir. Jerry Belson, 1987.

Suspect. Dir. Peter Yates, 1987.

Three Men and a Baby. Dir. Leonard Nimio, 1987.

Another Woman Dir. Woody Allen, 1988.

Crossing Delancey. Dir. Joan Micklin Silver, 1988. 
Genre and Ideology in Woody Allen's Another Woman (1988)

Immediate Family. Dir. Jonathan Kaplan, 1989.

Parenthood. Dir. Ron Howard, 1989.

Melinda and Melinda. Dir. Woody Allen, 2004.

Match Point. Dir. Woody Allen, 2005. 